\title{
HALAL LOGISTICS PERFORMANCE AND CUSTOMER LOYALTY: FROM THE LITERATURE REVIEW TO A CONCEPTUAL FRAMEWORK
}

\author{
Ilyas Masudin $^{1 *}$, Faradilla W. Fernanda ${ }^{2}$, Widayat $^{2}$ \\ ${ }^{I}$ Department of Industrial Engineering, Faculty of Engineering, Muhammadiyah University of \\ Malang, Jl. Raya Tlogomas 246, Malang 65144, Indonesia \\ ${ }^{2}$ Postgraduate Program of Management, Muhammadiyah University of Malang, Jl. Raya Tlogomas \\ 246, Malang 65152, Indonesia
}

(Received: April 2018 / Revised: May 2018 / Accepted: July 2018)

\begin{abstract}
Customer loyalty has become the most important goal of companies' logistics and supply chain divisions. In a Muslim country such as Indonesia, halal products have the potential power to foster customer loyalty. Halal status highly depends on halal logistics, especially with regard to halal meat products. A good halal meat product depends on good halal logistics performance. The influence of logistics performance on loyalty has been investigated in many marketing studies, but research in the field of halal logistics is rare. The research gap in this area has become the background for this conceptual paper. The main purpose of the paper is to provide a literature review of halal logistics performance and customer loyalty, thereby establishing the issues concerning both subjects. The review also provides a conceptual framework for the study, including other factors affecting customer loyalty, such as halal supplier service quality, perceived service value, and customer satisfaction.
\end{abstract}

Keywords: Customer loyalty; Customer satisfaction; Halal logistics; Logistics performance; Perceived service value

\section{INTRODUCTION}

Many logistics and supply chain management researchers have claimed that customer loyalty has economic and social impacts on companies (Gwinner et al., 1998; Mimouni-Chaabane \& Volle, 2010). This is because loyal customers help to maintain a company's market position, and often repurchase its products, even premium ones (Ngobo, 2016). That is why establishing loyalty is important as a strategic goal in all service (Gustafsson et al., 2005; Cooil et al., 2007). Therefore, many scholars have attempted to ascertain what factors contribute to loyalty (Zeithaml et al., 1996). One of these is logistics performance. This factor is investigated by researchers such as Mentzer et al. (2004), Richey et al. (2007), Stank et al. (2003), Day (2000), and Mattila (2001).

The relationship between logistics performance and loyalty is explained by Mentzer et al. (2004), Lai et al. (2009) and Hartono et al. (2017). They state that improving product quality through improvement in the performance of logistics activities will increase customer satisfaction. This means that logistics performance, which is one of the main factors influencing customer satisfaction, will in turn affect the loyalty of customers. Stank et al. (2003) concur that good logistics performance will create value for customers. However, firms must know exactly what type of logistics is useful in the market. Muslim countries such as Indonesia and Malaysia

\footnotetext{
*Corresponding author's email: masudin@umm.ac.id, Tel. +62-81232385876, Fax.+62-341460435 Permalink/DOI: https://dx.doi.org/10.14716/ijtech.v9i5.1919
} 
require halal products, which need halal logistics to maintain their halal status. This is especially the case for meat products, which need more complex halal logistics than other products because halal meat status starts from feeding cattle with halal food, up to halal meat displays in traditional and modern markets. Good halal logistics performance will improve halal meat product quality and create greater Muslim customer satisfaction. The research of Kumar et al. (2013), Aktepe et al. (2015), Kaura et al. (2015), Islam et al. (2016) has proven that customer satisfaction has a positive and direct effect on customer loyalty.

However, because halal logistics is still a new topic for scholars and practitioners, the amount of research in this area is still limited (Jaafar et al., 2016). Research in halal logistics and marketing still concerns customer perception (Tieman et al., 2013; Alqudsi, 2014), market analysis (Lever \& Miele, 2012), and retailer behavior (Kalantari et al., 2014). In this study, other factors that influence customer loyalty are discussed in five sections. Section 1 (the introduction) discusses the conceptual frameworks of customer loyalty and halal logistics performance developed in previous studies. The remainder of the study will be organized as follows: Section 2 discusses the halal meat market; the research methodology is presented in section 3; Section 4 presents the discussion; and the study is summarized in section 5 together with the conclusion.

\section{LITERATURE REVIEW}

\subsection{The Halal Meat Market and Halal Meat Logistics Requirements}

Before discussing halal meat, it is important to understand the halal food market. The main target of halal food marketing are Muslim customers. Grim and Karim (2011) estimated that the Muslim world population by 2030 will have reached 2.2 billion, or $26.4 \%$ of the total world population. The global halal market has grown very rapidly recently, coinciding with the accelerating development of Islam (Izberk-Bilgin \& Nakata, 2016). Muslim customer spending on food and beverage products is expected to have grown from \$1.17 trillion in 2015 to \$2.6 trillion by 2020 (Thomson Reuters, 2016). However, because the quantity of halal products is still limited, some Muslim countries have to import these from non-Muslim majority countries (Soesilowati, 2011). A study by Haque et al. (2015) showed that higher exports of halal food products from non-Muslim majority countries indicates that the market for halal food products in Muslim countries is growing rapidly. For example, the majority of halal meat and poultry products are currently produced by non-Muslim countries such as Australia, Argentina, Brazil, Uruguay and New Zealand, with most exported to Muslim countries (Zulfakar et al., 2017). This indicates an opportunity for Indonesia, as the world's largest Muslim country and major halal market, to be also a major producer of halal products (Soesilowati, 2011).

Meat is one of the major sources of protein and has social meaning in most communities (Fiddes, 1992). For Muslims, halal status is the major requirement before making a decision to purchase meat (Nakyinsige et al., 2012). "Halal" is a term which means permitted and allowed according to Islamic jurisprudence (Omar \& Jaafar, 2011), and is not only applied to physical products, but also to the process of production, distribution and sale (Kirwan, 2006). Therefore, the term halal refers to meat that is permitted to be consumed if the manufacturing process and meat quality are in accordance with Islamic jurisprudence. The process involves feeding halal food to cattle, halal slaughter processing, halal meat processing, and display in markets. Because the process is very complex, halal meat is vulnerable to becoming non-halal.

Because of this vulnerability, the demand for halal meat is high, especially from Muslim customers in non-Muslim majority areas. Jusmaliani and Nasution (2009) investigated Muslim customer behavior towards halal meat products in Jakarta and Melbourne. Their results show that halal meat availability is the only significant determinant factor in the behavior of Muslim 
customers in the two cities. In non-Muslim majority areas, halal processing (halal logistics) is mostly not used as a standard in the preparation of halal products, which makes it more difficult for Muslim customers to purchase products. Stitou and Rezgui (2012) conducted research on the Muslim community in France; their results show that $56 \%$ of the 223 Muslim respondents would not purchase a product if they were in any doubt about its halal status. Otherwise, $87 \%$ of respondents were willing to pay for a product that was guaranteed to be halal. This indicates the requirement for halal logistics from Muslim customers, especially in non-Muslim majority areas, even if it is more expensive than conventional logistics.

The willingness to pay for good halal logistics performance has been investigated in research by Kamaruddin et al. (2012), Tieman et al. (2013), and Fathi et al. (2016). Customers' perception of halal meat logistics was investigated by Tieman et al. (2013). Their research compares Muslim consumer behavior in Malaysia (a Muslim-majority country) with that in the Netherlands (a non-Muslim majority country). They found that Muslim consumers in Malaysia were more willing to pay for and request a higher segregation level than Muslim consumers in the Netherlands. However, the research obtained similar results to those of Stitou and Rezgui (2012) and Kamaruddin et al. (2012), finding that Muslim consumers are concerned about and are willing to pay for halal logistics, both in a Muslim-majority and non-Muslim majority countries. Research by Fathi et al. (2016) investigated the drivers of consumers' willingness to pay for halal logistics. According to their results, halal logistics certification of 3PL provider was the key factor in this willingness. Service capability and the image of 3PL are insignificant factors in creating the intention to pay for halal logistics, which indicates that companies should educate current/potential customers on halal logistics and emphasize its importance (Fathi et al., 2016).

\section{METHODOLOGY}

The review is limited to published literature, including theses and journals from Emerald, Elsevier, Google Scholar, etc. Keywords such as halal logistics, halal meat, loyalty, and customer satisfaction were used to find related studies. A special report that includes the halal food topic was used in the study, as the academic papers published on this subject matter are still limited. Only the few studies written in English are analysed, while some publications related to the study might not have been included. The number of sources needed to develop the framework was 104, with publication years ranging from 1988 to 2017. The type of publications reviewed can be divided into two classifications: 102 academic journal articles and 2 theses. From these, the articles were differentiated according to the main themes of the study, as shown in Table 1.

\subsection{Developing a Conceptual Framework}

Previous studies have found that the conventional factors of logistics operational performance such as product availability, product condition, delivery reliability and speed and service responsiveness positively affect customer satisfaction, customer loyalty and customers' repurchase intentions (Wang \& Sarker, 2006; Yuen, 2006). Moreover, in manufacturing five components of logistics performance measurement, namely asset management, cost, customer service, service quality and productivity, are the key components that can help a firm to build customer satisfaction and loyalty (Davis, 2006; Man, 2006; Wenbao, 2007; Fawcett et al., 2008).

Halal logistics performance and customer loyalty are rare topics in marketing and halal logistics research. For the purpose of developing a conceptual framework, research by Liang (2008) and Siu and Cheung (2001) are used as the main references. Liang (2008) investigated the relationship between logistics performance and customer loyalty in tourism; however, for halal 
logistics performance, this needs to be adapted by using the retail service quality measure by Siu and Cheung (2001). There are five variables: halal logistics performance; halal suppliers' service quality; perceived service value; customer satisfaction; and customer loyalty. Each variable will be discussed in the five sections below.

Table 1 Main themes of publications

\begin{tabular}{lll}
\hline \multicolumn{1}{c}{ Literature } & \multicolumn{1}{c}{ Component } & \multicolumn{1}{c}{ Main Theme } \\
\cline { 2 - 3 } & \multicolumn{1}{c}{ Customer satisfaction } & Customer loyalty \\
\hline Aktepe et al. (2015) & Customer satisfaction & Customer loyalty \\
Islam et al. (2016) & Customer satisfaction & Customer loyalty \\
Kumar et al. (2013) & Customer satisfaction & Customer loyalty \\
Lin \& Hsieh (2006) & Customer satisfaction & Customer loyalty \\
Kaura et al. (2015) & Perceived value & Customer satisfaction \\
Gallarza \& Saura (2006) & Perceived value & Customer satisfaction \\
Jhandir (2012) & Service quality & Perceived value \\
Cronin et al. (2000) & Service quality & Perceived value \\
Parasuraman \& Grewal (2000) & Personnel service quality & Service quality \\
Hartline \& Ferrell (1996) & Information system availability & Service quality \\
Buhalis \& Law (2008) & Product availability & Service quality \\
Kisperska-Moron (2005) & Service quality & Customer satisfaction \\
Baker \& Crompton (2000) & Service quality & Customer satisfaction \\
Lee \& Taylor (2005) & Service quality & Customer satisfaction \\
Teh \& Cabanban (2007) & Logistics performance & Customer satisfaction and loyalty \\
Man (2006) & Logistics performance & Customer satisfaction and loyalty \\
Wang \& Sarker (2006) & Logistics performance & Customer satisfaction and loyalty \\
Stank et al. (2003) & Logistics performance & Customer satisfaction and loyalty \\
Hovora (2001) & Logistics performance & Customer satisfaction and loyalty \\
Liang (2008) & Service quality & Service performance \\
Davis (2006) & Service quality & Service performance \\
Richey (2003) & Service quality & Service performance \\
Stank et al. (1999) & Dimension of logistics performance & Logistics performance \\
Mentzer et al. (1999) & & \\
\hline
\end{tabular}

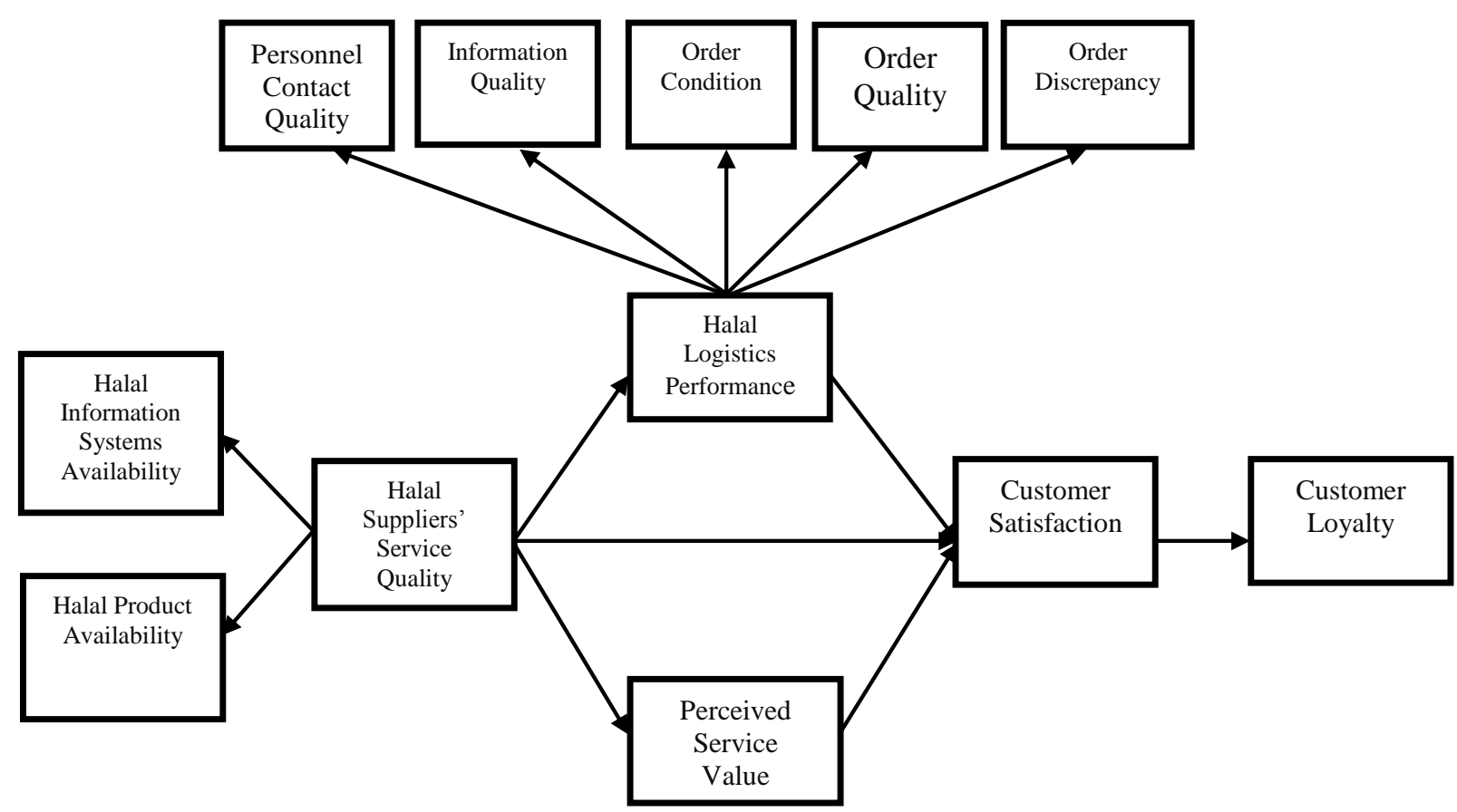

Figure 1 Conceptual framework of the factors that influence customer loyalty 


\section{RESULTS AND DISCUSSION}

\subsection{Halal Logistics Performance}

Halal logistics involves five stages of logistic activities, which apply the halal concept from the point of origin to the point of consumption (Omar \& Jaafar, 2011). To ensure that the halal concept is applied, halal certifiers must monitor all halal logistics activities. Examples of halal certifiers include Majelis Ulama Indonesia (MUI) and Jabatan Kemajuan Islam Malaysia (JAKIM), which are both operated by their respective governments. However, some countries use private halal laws and halal certifiers from private institutions, such as the Netherlands and the United States (Dahlan \& Sani, 2016). They will monitor all halal logistics activities at the breeding farms and abattoirs, and at the time when the halal meat is distributed and sold to domestic customers, halal meat importers, and the food industry (Omar \& Jaafar, 2011).

To build customer satisfaction and loyalty, logistics providers need to develop good logistics performance (Liang, 2008). According to Davis (2006), competitive advantage which is built by stronger customer relationships can be generated from good logistics performance. Logistic providers' ability to handle the ordering process will be measured by logistics performance (Stank et al., 1999; Mentzer et al., 2001; Stank et al., 2003; Mentzer et al., 2004; Ketikidis et al., 2006; Man, 2006). This performance is measured by the nine parameters of logistic service quality (LSQ) developed by Mentzer and Williams (2001). These concepts are personnel contact quality; order release quantities; information quality; ordering procedures; order accuracy; order condition; order quality; order discrepancy handling; and timeliness (Mentzer et al., 2001; Stank et al., 2003; Mentzer et al., 2004; Davis, 2006; Bienstock et al., 2008).

However, the subjects of our research are the end consumers of halal meat products. That is why the concepts need to be adopted so that they can be measured by the customer. Ordering procedures, timeliness, etc. cannot be measured because the customer cannot see them. To adapt the concepts, the research of Cheung (2001) is used. Therefore, the concepts used for halal logistics performance are personnel contact quality, information quality, order quality, order condition, and order discrepancy.

Personnel contact quality refers to customers' valuation of the treatment they receive from logistics suppliers' contact staff (Mentzer et al., 1999). It also refers to customers' perspective of how disrespectful personnel may be with regard to problems and situations facing them (DeCarlo \& Leigh, 1996; Hartline \& Ferrell, 1996). Tieman and Ghazali (2013) state that the foundation of halal logistics and the supply chain can be identified by direct personnel contact with a non-halal or haram (prohibited) substance, and contamination risk of the products. Moreover, a study by Ab Talib et al. (2015) found that halal personnel are the key reference point for religious customers to decide whether to purchase halal meat products.

Information quality refers to customers' perception of information about products which they may choose (Mentzer et al., 1999). Consumers will make decisions easily if information on products is available and complete (Mentzer et al., 2001). Information quality must be accurate, reliable and complete to support good logistics performance (Jie et al., 2012; Mohammadi \& Mukhtar, 2018). The halal critical points discussed by Lodhi (2010) identify that information quality in terms of complete tractability and a monitoring system of halal products throughout the entire halal meat supply chain should be available. This is in line with the findings of the study by Ab Talib et al. (2015), which shows that, similar to conventional logistics, information technology is also an important element for halal logistics performance.

Order quality refers to how well suppliers fulfil customers' needs with regard to a product and how well the products work (Novack et al., 1994; Mentzer et al., 1999). Order condition refers to the condition of products (their damage level ) (Mentzer et al., 1997). The difference between order quality and order condition is that order quality assesses how well products are made, 
while order condition assesses products' level of damage caused by the delivery process (Mentzer et al., 2001). An investigation by Wan Omar (2017) found that halal supply chain implementation performance is defined by the condition of the halal product as a result of the handling and delivery processes.

Order discrepancy refers to how well logistics providers handle any discrepancy after the order has reached customers (Rinehart et al., 1989). A study by Du and Tang (2014) developed a framework of how order discrepancy is one of the factors affecting customer satisfaction and loyalty. A framework and conceptual paper by Selim et al. (2018) consider order discrepancy handling as one of the drivers for successful halal logistics service quality.

\subsection{Halal Meat Supplier's Service Quality}

Positive service quality will generate positive word of mouth and repurchase behavior, which leads to customer loyalty (Liang, 2008). Similar findings were made by Chacko et al. (2006), who state that improving order and delivery efficiency and accuracy will improve customers' repurchase intention. The definition of service quality according to $\mathrm{Su}$ (2004) is how well customer needs are fulfilled by the service. Service quality can also be an accurate evaluation of all stages and operations when creating a service (Garvin, 1984). After the service is provided, a customer will measure how well it has met their expectations (Grönroos, 2000). In most service quality literature, expectation is defined as normative standards which meet future customer's needs (Boulding et al., 1993).

If a company provides bad quality service to a customer, the customer will avoid it, even if the company creates good promotions or campaigns (Berry \& Parasuraman, 1991). But if customers like the service, it will be an important advantage in market competition and will have greater effects than product quality and product price (Parasuraman \& Grewal, 2000). In this study, service quality refers to how well halal meat suppliers provide their service, which is measured by two dimensions: information system availability and product availability. Information system availability plays an important role in connecting suppliers with customers. It will be easier for customers to decide which products they want to buy with the help of the information system provided by suppliers (Liang, 2008). Product availability is an important element in service quality and will help to improve customer satisfaction (Mentzer \& Williams, 2001; Kisperska-Moron, 2005)

\subsection{Perceived Value}

The concept of value was introduced in the 1990s and since then it has become a general topic in marketing research (Sánchez-Fernández \& Iniesta-Bonillo, 2007). The definition of perceived value is customers' valuation of product functions based on their perception of the product price and the benefits received after using it (Zeithaml, 1988; Chahal \& Kumari, 2012). Perceived value can also be an evaluation of product benefit, cost, and the efforts that are needed for further analysis of a product (Daskin \& Kasim, 2016). According to Lee and Taylor (2005), a product has perceived value if: (1) its price is low; (2) it provides everything that a customer wants; (3) its price is proportional to its quality; and (4) the effort needed to buy is proportional to the product benefits. In line with this, Oh (2003) states that most consumers are concerned about price, quality, risk and the time spent when deciding to buy a product.

The perceived value of halal food consumption can be compared with the perceived value of organic food. When a consumer buys organic food, they assume that it is more delicious, healthier, and more environmentally friendly than non-organic food (McEachern \& McClean, 2002). Similarly, halal food consumers assume that by choosing a halal product it will make give them more peace of mind because they have obeyed religious rules in doing so (Jamal \& Sharifuddin, 2015). The interview results of their study show that Muslim customers expect suppliers to add a halal label to their halal products because it will make it easier for them to 
select and buy the product. That is in line with the research results of Chahal \& Kumari (2012) that show that perceived value has a positive impact on the intention to patronize a product, which leads to loyalty.

\subsection{Customer Satisfaction}

Customer satisfaction is an essential and a fundamental element in marketing (Brady \& Robertson, 2001; Kotler \& Armstrong, 2004). It is essential because it is very important for a marketer to fulfil customers' needs and desire for a product (Han \& Ryu, 2009). Paul et al. (2016) define customer satisfaction as a mental state in which a customer compares expectations before the purchase with their perception of product performance after the purchase. This valuation depends on product availability, information and demand. Customers will then compare expectations and perceptions based on these three factors. If customer expectations are fulfilled by the product performance, there will be positive perceptions of customer satisfaction (Lenka et al., 2009; Jhandir, 2012). Customer satisfaction is not a guarantee of repeat business, but the most dissatisfied customers will not buy again (La, 2005). Therefore, many industries use customer satisfaction as a criterion for assessing product performance (Anderson \& Sullivan, 1993). It can also serve as an exit barrier to protect customers from competitors' products (Gundersen et al., 1996). Satisfied customers tend to buy products from their chosen producer because if they switch to another product there will be the risk that it does not fulfil their expectations (Selnes, 1998).

\subsection{Customer Loyalty}

According to Oliver (1999), the definition of customer loyalty is the commitment to repeat purchase or patronize a product or brand consistently, although competitors or other situations could potentially cause customers to switch to other products. If the brand is not available on the market, consumers who are loyal will not instead buy another product (Patel \& Desai, 2016). The implications of consumer loyalty to a company include increasing revenues; reduction in the cost of new customer acquisition; and lower costs involved in handling repeat purchasers (Reichheld \& Sasser, 1990). The manifestation of customer loyalty in most marketing literature is repurchase behavior (Hennig-Thurau et al., 2002; Walker \& Francis, 2002; Yüksel \& Yüksel, 2007; Chi \& Qu, 2008; Litvin et al., 2008). However, according to Knox and Walker (2001), repurchase behavior is behavior that shows that customers repeatedly purchase products from the same company, while loyalty is more complex because it involves two components: psychology and behavior. In line with this, Liang (2008) argues that loyalty is not just a customer behavior on purchasing product, word of mouth and positive comments, but that not wanting to move to another product is also an indicator of customer loyalty (Liang, 2008).

\section{CONCLUSION}

The relationship between customer loyalty and logistics performance for halal meat products is an uncommon topic in the marketing research and halal logistics literature. This study offers a conceptual framework developed through relevant logistics and marketing literature. It will be very interesting for other researchers to improve this framework by taking a closer look at other factors that can influence customer loyalty. Moreover, this study could be investigated in greater detail to prove and improve the factors involved. The publication from research methodology can also be explored in future studies to fill the knowledge gap in this subject.

\section{REFERENCES}

Ab Talib, M.S., Abdul Hamid, A.B., Zulfakar, M.H., 2015. Halal Supply Chain Critical Success Factors: A Literature Review. Journal of Islamic Marketing, Volume 6(1), pp. 44-71 
Aktepe, A., Ersöz, S., Toklu, B., 2015. Customer Satisfaction and Loyalty Analysis with Classification Algorithms and Structural Equation Modeling. Computers \& Industrial Engineering, Volume 86, pp. 95-106

Alqudsi, S.G., 2014. Awareness and Demand for 100\% Halal Supply Chain Meat Products. Procedia-Social and Behavioral Sciences, Volume 130, pp. 167-178

Anderson, E.W., Sullivan, M.W., 1993. The Antecedents and Consequences of Customer Satisfaction for Firms. Marketing Science, Volume 12(2), pp. 125-143

Baker, D.A., Crompton, J.L., 2000. Quality, Satisfaction and Behavioral Intentions. Annals of Tourism Research, Volume 27(3), pp. 785-804

Berry, L.L., Parasuraman, A., 1991. Marketing Services: Competing through Quality. Journal of Marketing, Volume 56(2), pp. 132-134

Bienstock, C.C., Royne, M.B., Sherrell, D., Stafford, T.F., 2008. An Expanded Model of Logistics Service Quality: Incorporating Logistics Information Technology. International Journal of Production Economics, Volume 113(1), pp. 205-222

Boulding, W., Kalra, A., Staelin, R., Zeithaml, V.A., 1993. A Dynamic Process Model of Service Quality: From Expectations to Behavioral Intentions. Journal of Marketing Research, Volume 30(1), pp. 7-27

Brady, M.K., Robertson, C.J., 2001. Searching for a Consensus on the Antecedent Role of Service Quality and Satisfaction: an Exploratory Cross-National Study. Journal of Business Research, Volume 51(1), pp. 53-60

Buhalis, D., Law, R., 2008. Progress in Information Technology and Tourism Management: 20 Years on and 10 Years after the Internet-The State of eTourism Research. Tourism Management, Volume 29(4), pp. 609-623

Chacko, H., Davidson, M., Green, Y., 2006. The 'Big Easy or the Hard Ask': A Case Study of Service Quality in New Orleans Hotels. Journal of Hospitality \& Leisure Marketing, Volume 13(3-4), pp. 183-205

Chahal, H., Kumari, N., 2012. Consumer Perceived Value: The Development of a Multiple Item Scale in Hospitals in the Indian Context. International Journal of Pharmaceutical and Healthcare Marketing, Volume 6(2), pp. 167-190

Chi, C.G.-Q., Qu, H., 2008. Examining the Structural Relationships of Destination Image, Tourist Satisfaction and Destination Loyalty: An Integrated Approach. Tourism Management, Volume 29(4), pp. 624-636

Cooil, B., Keiningham, T.L., Aksoy, L., Hsu, M., 2007. A Longitudinal Analysis of Customer Satisfaction and Share of Wallet: Investigating the Moderating Effect of Customer Characteristics. Journal of Marketing, Volume 71(1), pp. 67-83

Cronin, J.J., Brady, M.K., Hult, G.T.M., 2000. Assessing the Effects of Quality, Value, and Customer Satisfaction on Consumer Behavioral Intentions in Service Environments. Journal of Retailing, Volume 76(2), pp. 193-218

Dahlan, H.A., Sani, N.A., 2016. "Halal Laws": From Conception to Current Challenges. In: Proceedings of the Persiswa Law Conference 2016 (Persloc 2016), 23-24 July 2016, Malaysia

Daskin, M., Kasim, A., 2016. Exploring the Impact of Service Recovery on Customer Affection, Perceived Value, and Sabotaging Behaviour: Does Gender Make a Difference? International Journal of Services and Operations Management, Volume 23(4), pp. 467485

Davis, E.R., 2006. The Role of Logistics Service Quality in Creating Customer Loyalty. Doctoral Dissertation, University of Tennessee, Knoxville

Day, G.S., 2000. Managing Market Relationships. Journal of the Academy of Marketing Science, Volume 28(1), pp. 24-30 
DeCarlo, T.E., Leigh, T.W., 1996. Impact of Salesperson Attraction on Sales Managers' Attributions and Feedback. The Journal of Marketing, pp. 47-66

Du, Y., Tang, Y., 2014. A Literature Review on the Relationship Between Service Quality and Customer Loyalty. Business and Management Research, Volume 3(3), pp. 27-33

Fathi, E., Zailani, S., Iranmanesh, M., Kanapathy, K., 2016. Drivers of Consumers' Willingness to Pay for Halal Logistics. British Food Journal, Volume 118(2), pp. 464-479

Fawcett, S.E., Magnan, G.M., McCarter, M.W., 2008. Benefits, Barriers, and Bridges to Effective Supply Chain Management. Supply Chain Management: An International Journal, Volume 13(1), pp. 35-48

Fiddes, N., 1992. Meat : A Natural Symbol. Routledge, New York

Gallarza, M.G., Saura, I.G., 2006. Value Dimensions, Perceived Value, Satisfaction and Loyalty: An Investigation of University Students' Travel Behaviour. Tourism Management, Volume 27(3), pp. 437-452

Garvin, D., 1984. What Does Product Quality Really Mean? Sloan Management Review, Volume 25 (1), pp. 1-19

Grim, B.J., Karim, M.S., 2011. The Future of the Global Muslim Population: Projections for 2010-2030. Pew Research Center, Washington DC

Grönroos, C., 2000. Service Management and Marketing: A Customer Relationship Management Approach. John Wiley \& Sons Ltd, Chichester, England

Gundersen, M.G., Heide, M., Olsson, U.H., 1996. Hotel Guest Satisfaction among Business Travelers. Cornell Hospitality Quarterly, Volume 37(2), pp. 72-81

Gustafsson, A., Johnson, M.D., Roos, I., 2005. The Effects of Customer Satisfaction, Relationship Commitment Dimensions, and Triggers on Customer Retention. Journal of Marketing, Volume 69(4), pp. 210-218

Gwinner, K.P., Gremler, D.D., Bitner, M.J., 1998. Relational Benefits in Services Industries: the Customer's Perspective. Journal of the Academy of Marketing Science, Volume 26(2), pp. 101-114

Han, H., Ryu, K., 2009. The Roles of the Physical Environment, Price Perception, and Customer Satisfaction in Determining Customer Loyalty in the Restaurant Industry. Journal of Hospitality \& Tourism Research, Volume 33(4), pp. 487-510

Haque, A., Sarwar, A., Yasmin, F., Tarofder, A.K., Hossain, M.A., 2015. Non-Muslim Consumers' Perception toward Purchasing Halal Food Products in Malaysia. Journal of Islamic Marketing, Volume 6(1), pp. 133-147

Hartline, M.D., Ferrell, O.C., 1996. The Management of Customer-Contact Service Employees: An Empirical Investigation. The Journal of Marketing, pp. 52-70

Hartono, M., Santoso, A., Prayogo, D.N., 2017. How Kansei Engineering, Kano and QFD can Improve Logistics Services. International Journal of Technology, Volume 8(6), pp. 1070 1081

Hennig-Thurau, T., Gwinner, K.P., Gremler, D.D., 2002. Understanding Relationship Marketing Outcomes an Integration of Relational Benefits and Relationship Quality. Journal of Service Research, Volume 4(3), pp. 230-247

Hovora, J., 2001. Logistics in Onboard Services (Inflight Services) of Airlines. Tourism and Hospitality Research, Volume 3(2), pp. 177-180

Islam, M.J., Mustaf, M.A.A., Azmi, T., Ahmed, F., 2016. Measuring the Effect of Retail Service Quality Dimensions on Customer Satisfaction and Loyalty: The Study on the Super Shop in Bangladesh. International Journal of Scientific \& Engineering Research, Volume 7 (8), pp. 215-233

Izberk-Bilgin, E., Nakata, C.C., 2016. A New Look at Faith-Based Marketing: The Global Halal Market. Business Horizons, Volume 59(3), pp. 285-292 
Jaafar, H.S., Faisol, N., Rahman, F.A., Muhammad, A., 2016. Halal Logistics Versus Halal Supply Chain: A Preliminary Insight Contemporary Issues and Development in the Global Halal Industry, pp. 579-588

Jamal, A., Sharifuddin, J., 2015. Perceived Value and Perceived Usefulness of Halal Labeling: The Role of Religion and Culture. Journal of Business Research, Volume 68(5), pp. 933941

Jhandir, S.U., 2012. Customer Satisfaction, Perceived Service Quality and Mediating Role of Perceived Value. International Journal of Marketing Studies, Volume 4(1), pp. 1-9

Jie, F., Parton, K.A., Cox, R.J., 2012. An Agile Supply Chain Analysis of Australian Beef Wholesalers and Retailers. International Journal of Agile Systems and Management, Volume 5(4), pp. 297-318

Jusmaliani, J., Nasution, H., 2009. Religiosity Aspect in Consumer Behaviour: Determinants of Halal Meat Consumption. ASEAN Marketing Journal, Volume 1, pp. 1-11

Kalantari Shahijan, M., Rezaei, S., Christopher Preece, N., Khairuzzaman Wan Ismail, W., 2014. Examining Retailers' Behaviour in Managing Critical Points in Halal Meat Handling: A PLS Analysis. Journal of Islamic Marketing, Volume 5(3), pp. 446-472

Kamaruddin, R., Iberahim, H., Shabudin, A., 2012. Willingness to Pay for Halal Logistics: The Lifestyle Choice. Procedia-Social and Behavioral Sciences, Volume 50, pp. 722-729

Kaura, V., Durga Prasad, C.S., Sharma, S., 2015. Service Quality, Service Convenience, Price and Fairness, Customer Loyalty, and the Mediating Role of Customer Satisfaction. International Journal of Bank Marketing, Volume 33(4), pp. 404-422

Ketikidis, P.H., Lenny Koh, S., Gunasekaran, A., Cheung, C., Chan, Y., Kwok, S., Wang, W., 2006. A Knowledge-Based Service Automation System for Service Logistics. Journal of Manufacturing Technology Management, Volume 17(6), pp. 750-771

Kirwan, J., 2006. The Interpersonal World of Direct Marketing: Examining Conventions of Quality at UK Farmers' Markets. Journal of Rural Studies, Volume 22(3), pp. 301-312

Kisperska-Moron, D., 2005. Logistics Customer Service Levels in Poland: Changes between 1993 and 2001. International Journal of Production Economics, Volume 93, pp. 121-128

Knox, S., Walker, D., 2001. Measuring and Managing Brand Loyalty. Journal of Strategic Marketing, Volume 9(2), pp. 111-128

Kotler, P., Armstrong, G., 2004. Principles of Marketing. NJ Prentice Hall, Upper Saddle River

Kumar, V., Dalla Pozza, I., Ganesh, J., 2013. Revisiting the Satisfaction-Loyalty Relationship: Empirical Generalizations and Directions for Future Research. Journal of Retailing, Volume 89(3), pp. 246-262

La, K.V., 2005. Customer Loyalty in Web-based Retailing. Doctor of Philosophy's Dissertation, Royal Melbourne Institute of Technology, Melbourne

Lai, F., Griffin, M., Babin, B.J., 2009. How Quality, Value, Image, and Satisfaction Create Loyalty at a Chinese Telecom. Journal of Business Research, Volume 62(10), pp. 980-986

Lee, C.-K., Taylor, T., 2005. Critical Reflections on the Economic Impact Assessment of a Mega-event: The Case of 2002 FIFA World Cup. Tourism Management, Volume 26(4), pp. 595-603

Lenka, U., Suar, D., Mohapatra, P.K., 2009. Service Quality, Customer Satisfaction, and Customer Loyalty in Indian Commercial Banks. Journal of Entrepreneurship, Volume 18(1), pp. 47-64

Lever, J., Miele, M., 2012. The Growth of Halal Meat Markets in Europe: An Exploration of the Supply Side Theory of Religion. Journal of Rural Studies, Volume 28(4), pp. 528-537

Liang, H.-C., 2008. Impact of Logistic Service Performance on Tourist Satisfaction and Loyalty. RMIT University, Melbourne 
Lin, J.-S.C., Hsieh, P.-1., 2006. The Role of Technology Readiness in Customers' Perception and Adoption of Self-service Technologies. International Journal of Service Industry Management, Volume 17(5), pp. 497-517

Litvin, S.W., Goldsmith, R.E., Pan, B., 2008. Electronic Word-of-Mouth in Hospitality and Tourism Management. Tourism Management, Volume 29(3), pp. 458-468

Lodhi, A.-u.-H., 2010. Understanding halal food supply chain. Hfrc Uk Limited, London

Man, Y.S., 2006. Performance Measurement and Management of Third Party Logistics: An Organizational Theory Approach. Hong Kong Baptist University, Hong Kong

Mattila, A.S., 2001. The Impact of Relationship Type on Customer Loyalty in a Context of Service Failures. Journal of Service Research, Volume 4(2), pp. 91-101

McEachern, M.G., Mcclean, P., 2002. Organic Purchasing Motivations and Attitudes: Are They Ethical? International Journal of Consumer Studies, Volume 26(2), pp. 85-92

Mentzer, J.T., Flint, D.J., Hult, G.T.M., 2001. Logistics Service Quality as a SegmentCustomized Process. Journal of Marketing, Volume 65(4), pp. 82-104

Mentzer, J.T., Flint, D.J., Kent, J.L., 1999. Developing a Logistics Service Quality Scale. Journal of Business Logistics, Volume 20(1), pp. 1-68

Mentzer, J.T., Myers, M.B., Cheung, M.-S., 2004. Global Market Segmentation for Logistics Services. Industrial Marketing Management, Volume 33(1), pp. 15-20

Mentzer, J.T., Rutner, S.M., Matsuno, K., 1997. Application of the Means-end Value Hierarchy Model to Understanding Logistics Service Value. International Journal of Physical Distribution \& Logistics Management, Volume 27(9-10), pp. 630-643

Mentzer, J.T., Williams, L.R., 2001. The Role of Logistics Leverage in Marketing Strategy. Journal of Marketing Channels, Volume 8(3-4), pp. 29-47

Mimouni-Chaabane, A., Volle, P., 2010. Perceived Benefits of Loyalty Programs: Scale Development and Implications for Relational Strategies. Journal of Business Research, Volume 63(1), pp. 32-37

Mohammadi, M., Mukhtar, M., 2018. Comparison of Supply Chain Process Models Based on Service-Oriented Architecture. International Journal of Technology, Volume 9(1), pp. 3545

Nakyinsige, K., Che Man, Y., Sazili, A., Zulkifli, I., Fatimah, A., 2012. Halal Meat: A Niche Product in the Food Market. In: $2^{\text {nd }}$ International Conference on Economics, Trade and Development IPEDR 2012

Ngobo, P.V., 2016. The Trajectory of Customer Loyalty: An Empirical Test of Dick and Basu's Loyalty Framework. Journal of the Academy of Marketing Science, Volume 45(2), pp. 122

Novack, R.A., Rinehart, L.M., Langley Jr, C.J., 1994. An Internal Assessment of Logistics Value. Journal of Business Logistics, Volume 15(1), pp. 113-152

Oh, H., 2003. Price Fairness and Its Asymmetric Effects on Overall Price, Quality, and Value Judgments: The Case of an Upscale Hotel. Tourism Management, Volume 24(4), pp. 387399

Oliver, R.L., 1999. Whence Consumer Loyalty? The Journal of Marketing, Volume 63(33), pp. $33-44$

Omar, E.N., Jaafar, H.S., 2011. Halal Supply Chain in the Food Industry-A Conceptual Model. In: Proceedings of the IEEE Symposium on Business, Engineering and Industrial Applications (ISBEIA), 25-28 September 2011, Langkawi, Malaysia

Parasuraman, A., Grewal, D., 2000. The Impact of Technology on the Quality-Value-Loyalty Chain: A Research Agenda. Journal of the Academy of Marketing Science, Volume 28(1), pp. $168-174$ 
Patel, H.D., Desai, M.P., 2016. A Study on Relation between Customer Satisfaction, Customer Loyalty and Intention to Switch from One Bank to Another Bank in Surat City. Adarsh Journal of Management Research, Volume 9(1), pp. 1-13

Paul, J., Mittal, A., Srivastav, G., 2016. Impact of Service Quality on Customer Satisfaction in Private and Public Sector Banks. International Journal of Bank Marketing, Volume 34(5)

Reichheld, F., Sasser, W., 1990. Zero Defections: Quality Comes to Service. Harvard Business Review, Volume 68(5), pp. 105-111

Reuters, T., 2016. State of the Global Economic Islamic Report 2016/17. Thomson Reuters

Richey, R.G., 2003. Technological Readiness and Strategic Interactive Fit: Dynamic Capabilities Impacting Logistics Service Competency and Performance. Doctor of Philosophy's Dissertation, The University of Oklahoma, Norman, Oklahoma

Richey, R.G., Daugherty, P.J., Roath, A.S., 2007. Firm Technological Readiness and Complementarity: Capabilities Impacting Logistics Service Competency and Performance. Journal of Business Logistics, Volume 28(1), pp. 195-228

Rinehart, L.M., Cooper, M.B., Wagenheim, G.D., 1989. Furthering the Integration of Marketing and Logistics through Customer Service in the Channel. Journal of the Academy of Marketing Science, Volume 17(1), pp. 63-71

Sánchez-Fernández, R., Iniesta-Bonillo, M.Á., 2007. The Concept of Perceived Value: A Systematic Review of the Research. Marketing Theory, Volume 7(4), pp. 427-451

Selim, N.I.I.B., Zailani, S.H.B.D.M., Aziz, A.A.B., 2018. Halal Logistics Service Quality (HLSQ) by Third-Party Providers (3PL) in Malaysia: A Conceptual Paper. In: Proceedings of the $3^{\text {rd }}$ International Halal Conference (INHAC 2016), 21-22 November 2016, Malaysia

Selnes, F., 1998. Antecedents and Consequences of Trust and Satisfaction in Buyer-Seller Relationships. European Journal of Marketing, Volume 32(3/4), pp. 305-322

Siu, N.Y., Tak-Hing Cheung, J., 2001. A Measure of Retail Service Quality. Marketing Intelligence \& Planning, Volume 19(2), pp. 88-96

Soesilowati, E.S., 2011. Business Opportunities for Halal Products in the Global Market: Muslim Consumer Behaviour and Halal Food Consumption. Journal of Indonesian Social Sciences and Humanities, Volume 3, pp. 151-160

Stank, T.P., Goldsby, T.J., Vickery, S.K., 1999. Effect of Service Supplier Performance on Satisfaction and Loyalty of Store Managers in the Fast Food Industry. Journal of Operations Management, Volume 17(4), pp. 429-447

Stank, T.P., Goldsby, T.J., Vickery, S.K., Savitskie, K., 2003. Logistics Service Performance: Estimating its Influence on Market Share. Journal of Business Logistics, Volume 24(1), pp. 27-55

Stitou, N., Rezgui, H., 2012. The Muslim Consumer as the Key Player in Halal. ASIDCOM Report, France

Su, A.Y.-L., 2004. Customer Satisfaction Measurement Practice in Taiwan Hotels. International Journal of Hospitality Management, Volume 23(4), pp. 397-408

Teh, L., Cabanban, A.S., 2007. Planning for Sustainable Tourism in Southern Pulau Banggi: An Assessment of Biophysical Conditions and Their Implications for Future Tourism Development. Journal of Environmental Management, Volume 85(4), pp. 999-1008

Tieman, M., Ghazali, M.C., 2013. Principles in Halal Purchasing. Journal of Islamic Marketing, Volume 4(3), pp. 281-293

Tieman, M., Ghazali, M.C., Van Der Vorst, J.G., 2013. Consumer Perception on Halal Meat Logistics. British Food Journal, Volume 115(8), pp.1112-1129

Walker, R.H., Francis, H., 2002. Customer Service and Relationship Management in the Context of Technology-Enabled Service Delivery Systems-Managerial and Research Implications. In: Proceedings of the Australian and New Zealand Marketing Academy Conference, 2-4 December 2002, Melbourne, Victoria 
Wan Omar, W., 2017. Developing a Model for Halal Food Supply Chain Implementation. Doctor of Philosophy's Dissertation, RMIT University, Melbourne, Australia

Wang, S., Sarker, B.R., 2006. Optimal Models for a Multi-stage Supply Chain System Controlled by Kanban under Just-in-time Philosophy. European Journal of Operational Research, Volume 172(1), pp. 179-200

Wenbao, L., 2007. The Exploration of Customer Satisfaction Model from a Comprehensive Perspective. Expert Systems with Applications, Volume 33(1), pp. 110-121

Yuen, S.M., 2006. Performance Measurement and Management of Third Party Logistics: An Organizational Theory Approach. Master's Thesis, Graduate Program, Hong Kong Baptist University, Hong Kong

Yüksel, A., Yüksel, F., 2007. Shopping Risk Perceptions: Effects on Tourists' Emotions, Satisfaction and Expressed Loyalty Intentions. Tourism Management, Volume 28(3), pp. 703-713

Zeithaml, V.A., Berry, L.L., Parasuraman, A., 1996. The Behavioral Consequences of Service Quality. The Journal of Marketing, Volume 60(2), pp. 31-46

Zeithaml Valarie, A., 1988. Consumer Perception of Price, Quality, and Value: A Means-end Model and Synthesys of Evidence. Journal of Marketing, Volume 6(3), pp. 2-22

Zulfakar, M.H., Chan, C., Jie, F., 2017. Institutional Forces on Australian Halal Meat Supply Chain (AHMSC) Operations. Journal of Islamic Marketing, Volume 9(1), pp. 80-98 